\title{
Heme oxygenase-1/biliverdin/carbon monoxide pathway downregulates hypernociception in rats by a mechanism dependent on cGMP/ATP-sensitive $\mathrm{K}^{+}$channels
}

\author{
Hellíada Vasconcelos Chaves ${ }^{1}$ - Danielle Rocha do Val ${ }^{2} \cdot$ Kátia Alves Ribeiro $^{3}$. Jonas Cavalcante Lemos ${ }^{4}$. \\ Ricardo Basto Souza ${ }^{3}$. Francisco Isaac Fernandes Gomes ${ }^{1}$. Rodrigo Maranguape Silva da Cunha ${ }^{5}$. \\ Vicente de Paulo Teixeira Pinto ${ }^{4}$. Gerardo Cristino Filho ${ }^{4}$. Marcellus Henrique Loiola Ponte de Souza ${ }^{6}$. \\ Mirna Marques Bezerra ${ }^{4}$. Gerly Anne de Castro Brito ${ }^{6}$
}

Received: 15 April 2017 / Revised: 14 December 2017 / Accepted: 17 January 2018

○) Springer International Publishing AG, part of Springer Nature 2018

\begin{abstract}
Objective and design To investigate the role of heme oxygenase-1 (HO-1), carbon monoxide (CO), and biliverdin (BVD) in the zymosan-induced TMJ arthritis in rats.

Materials and Methods Mechanical threshold was assessed before and $4 \mathrm{~h}$ after TMJ arthritis induction in rats. Cell influx, myeloperoxidase activity, and histological changes were measured in the TMJ lavages and tissues. Trigeminal ganglion and periarticular tissues were used for HO-1, TNF- $\alpha$, and IL-1 $\beta$ mRNA time course expression and immunohistochemical analyses. Hemin $\left(0.1,0.3\right.$, or $\left.1 \mathrm{mg} \mathrm{kg}^{-1}\right)$, DMDC $\left(0.025,0.25\right.$, or $\left.2.5 \mu \mathrm{mol} \mathrm{kg}{ }^{-1}\right)$, biliverdin $\left(1,3\right.$, or $\left.10 \mathrm{mg} \mathrm{kg}^{-1}\right)$, or ZnPP-IX $\left(1,3\right.$ or $\left.9 \mathrm{mg} \mathrm{kg}^{-1}\right)$ were injected (s.c.) 60 min before zymosan. ODQ $\left(12.5 \mu \mathrm{mol} \mathrm{kg}-1\right.$; s.c.) or glibenclamide $\left(10 \mathrm{mg} \mathrm{kg}^{-1}\right.$; i.p.) was administered $1 \mathrm{~h}$ and $30 \mathrm{~min}$ prior to DMDC $\left(2.5 \mu \mathrm{mol} \mathrm{kg}^{-1}\right.$; s.c), respectively.

Results Hemin $\left(1 \mathrm{mg} \mathrm{kg}^{-1}\right)$, DMDC $\left(2.5 \mu \mathrm{mol} \mathrm{kg}{ }^{-1}\right)$, and BVD $\left(10 \mathrm{mg} \mathrm{kg}^{-1}\right)$ reduced hypernociception and leukocyte migration, which ZnPP $\left(3 \mathrm{mg} \mathrm{kg}^{-1}\right)$ enhanced. The effects of DMDC were counteracted by ODQ and glibenclamide. The HO- 1 , TNF- $\alpha$, and IL- $1 \beta$ mRNA expression and immunolabelling increased.

Conclusions $\mathrm{HO}-1 / \mathrm{BVD} / \mathrm{CO}$ pathway activation provides anti-nociceptive and anti-inflammatory effects on the zymosaninduced TMJ hypernociception in rats.
\end{abstract}

Keywords Inflammation $\cdot \mathrm{IL}-1 \beta \cdot$ Heme oxygenase- $1 \cdot$ Temporomandibular joint $\cdot$ TNF- $\alpha$.

Responsible Editor: Mauro Teixeira.

Hellíada Vasconcelos Chaves

helliadachaves@yahoo.com.br

1 Faculty of Dentistry of Sobral, Federal University of Ceará, Avenida Comandante Maurocélio Rocha Pontes, 100, Derby, Sobral CEP: 62.042-280, Brazil

2 Federal University of Pernambuco, North Eastern Biotechnology Network, Recife, Brazil

3 Master of Biotechnology Degree Programme, Federal University of Ceará, Sobral, Brazil

4 Faculty of Medicine, Federal University of Ceará, Sobral, Brazil

5 Biotechnology Research Group, State University of Acaraú Valley, Sobral, Ceará, Brazil

6 Department of Physiology and Pharmacology, Faculty of Medicine, Federal University of Ceará, Fortaleza, Brazil

\author{
Abbreviations \\ DMDC Dimethyl dicarbonate \\ ZnPP-IX Zinc protoporphyrin IX \\ ODQ 1H- [1,2,4] oxadiazolo[4,3,-a]quinoxalin-1-one \\ TNF- $\alpha$ Tumor necrosis factor-alpha \\ IL-1 $\beta \quad$ Interleukin-1beta
}

\section{Introduction}

Temporomandibular joint (TMJ) arthritis encompasses a group of musculoskeletal and neuromuscular disorders. It possesses diverse signs and symptoms which are frequently associated with acute or persistent pain [1-3]. Experimental models that allow the study of the TMJ inflammatory pain mechanisms are of great clinical relevance. It is known that zymosan, a polysaccharide from yeast cell walls, produces 
a severe and erosive synovitis that is also associated with hyperalgesia and gait disturbances [4-6].

We developed a rat model of zymosan-induced TMJ arthritis during in which animals present maximal hypernociception between 4 and $6 \mathrm{~h}$ after zymosan injection [7]. It exhibits clinical and histopathological features like the human counterpart and has helped us understand the molecular mechanisms involved in the pathogenesis of TMJ inflammatory pain. A variety of inflammatory mediators are involved in the zymosan-induced TMJ arthritis such as nitric oxide (NO), reactive oxygen species, and cytokines (IL- $1 \beta$, TNF $\alpha$, and IL-6), but no evidence of the involvement of heme oxygenase $(\mathrm{HO})$ in the TMJ inflammatory pain has been revealed [7-9].

$\mathrm{HO}$ catalyzes heme degradation to iron, sequestered by ferritin, carbon monoxide (CO), and biliverdin, which is reduced to bilirubin-by-biliverdin reductase [10]. Ferritin, biliverdin, and bilirubin are antioxidant molecules, and $\mathrm{CO}$ suppresses the synthesis of inflammatory mediators and exhibits some properties like those of NO. One of the main mechanisms of action of $\mathrm{CO}$ is to activate guanylyl cyclase resulting in production of cGMP which in turn activates several types of $\mathrm{K}+$ channels leading to hyperpolarization [11-17].

To date, three isoforms of HO have been identified. HO-1 is inducible by a variety of cells, including endothelial cells, monocytes/macrophages, neutrophils and fibroblasts, by heme, endo-heme, endotoxins, cytokines, nitric oxide, reactive oxygen species, hypoxia and hyperoxia, and other mediators produced during inflammatory responses, whereas HO-2 and a spliced variant of HO-2 are constitutively expressed [18-20]. Many studies indicate a link between HO-1 and inflammation [12, 16, 18, 21]. Thus, this study aims to evaluate the unexplored role of $\mathrm{HO}-1 /$ biliverdin or HO-1/CO/cGMP/ATP-sensitive $\mathrm{K}^{+}$channel pathway in the modulation of zymosan-induced TMJ inflammatory hypernociception in rats.

\section{Methods}

\section{Animals}

Male Wistar rats (160-220 g) were housed in standard plastic cages with food and water available ad libitum. They were maintained in a temperature-controlled room $\left(23 \pm 2{ }^{\circ} \mathrm{C}\right)$ with a $12 / 12$-h light-dark cycle. All experiments were designed to minimize animal suffering and to use the minimum number of animals required to achieve a valid statistical evaluation. This study was conducted in accordance with the Helsinki declaration as well as the International Association for the Study of Pain (IASP) for the care and use of animals. In addition, the Institutional Animal Care and
Use Committee of the Federal University of Ceará guidelines approved this protocol under the registration number 26/08.

\section{TMJ arthritis induction}

Rats were anesthetized with tribromoethanol $\left(0.01 \mathrm{~mL} \mathrm{~g}^{-1}\right.$, i.p.) and received an intra-articular (i.art.) injection of 1 or $2 \mathrm{mg}$ zymosan ( $40 \mu \mathrm{L}$ total volume) dissolved in sterile saline into the left TMJ using a 29-gauge needle and $0.5 \mathrm{~mL}$ syringe. Sham animals received saline i.art. Before zymosan or saline injections, the TMJ skin region was carefully shaved, the posteroinferior border of the zygomatic arch was palpated, and the needle was inserted inferior to this point and advanced in a medial and anterior direction until the needle contacted the condyle. This contact was verified by the moving of the mandible, and the puncture of the needle into the joint space was confirmed by the loss of resistance. Gentle aspiration ruled out intravascular placement, after which the specified volume of zymosan or saline was injected. As shown by our group [7], the zymosan-induced TMJ inflammatory hypernociception development is maximal at $4 \mathrm{~h}$ of arthritis, whereas cell influx peaks at $6 \mathrm{~h}$. Based on these results, we used these timepoints to assess both nociceptive (head withdrawal threshold) and inflammatory parameters (total cell counting and myeloperoxidase assay).

\section{Evaluation of inflammatory hypernociception}

Inflammatory hypernociception in the TMJ was evaluated by measuring the threshold of force intensity that needed to be applied to the TMJ region until the occurrence of a reflex response of the animal (e.g., head withdrawal). The measurements were performed by an examiner unaware of the treatments and used a digital device (Insight, Ribeirão Preto, SP, Brazil) that consisted of a rigid filament linked to an electronic device that measured the response threshold in grams $(\mathrm{g})$ when the filament was applied to the surface of the tested region. The facial areas to be tested around the TMJ were carefully shaved, and the animals were put into individual plastic cages $45 \mathrm{~min}$ before the beginning of the tests. The animals were submitted to a conditioning session of head withdrawal threshold measurements in the testing room for 4 consecutive days under controlled temperatures $\left(23 \pm 2{ }^{\circ} \mathrm{C}\right)$ and low illumination. On day 5 , the basal force threshold value was recorded (in triplicate) before the i.art. injections of either zymosan or vehicle and after $4 \mathrm{~h}$.

\section{Synovial lavage collection and cell counting}

Zymosan injection (i.art) was performed in anesthetized rats. Six hours after zymosan-induced TMJ arthritis, the rats were sacrificed under anesthesia and exsanguinated. 
The superficial tissues were dissected, and the TMJ cavity was washed to collect the synovial lavage by a pumping and aspiration technique using $0.5 \mathrm{~mL}$ of EDTA in neutral buffered PBS. This procedure was repeated twice. The total number of white cells in the synovial lavage was counted using a Neubauer chamber.

\section{Myeloperoxidase activity analysis}

Myeloperoxidase (MPO) is an enzyme found primarily in the azurophilic granules of the neutrophils and has been used extensively as a biochemical marker of granulocyte infiltration into various tissues. The MPO activity assay measurement was previously described [22]. In our study, the MPO assay was conducted on the collected synovial lavage $6 \mathrm{~h}$ after the zymosan-induced TMJ arthritis. MPO activity in the collected synovial lavage was assayed by measuring the change in absorbance at $450 \mathrm{~nm}$ using o-dianisidine dihydrochloride and $1 \%$ hydrogen peroxide. The results are reported as the MPO units/joint lavage. A unit of MPO activity was defined as the conversion of 1 $\mu \mathrm{mol}$ of hydrogen peroxide to water in $1 \mathrm{~min}$ at $22^{\circ} \mathrm{C}$.

\section{Histopathological analysis}

Six hours after the zymosan-induced arthritis animals were sacrificed and the TMJ was excised. The specimens were fixed in $10 \%$ neutral buffered formalin for $24 \mathrm{~h}$, demineralized in 10\% EDTA, embedded in paraffin, and sectioned along the long axis of the TMJ. Sections of 5 $\mu \mathrm{m}$, which included the condyle, articular cartilage, articular disc, synovial membrane, periarticular tissue, and the skeletal muscle periarticular tissue, were evaluated under light microscopy. For the specimens processed for routine hematoxylin-eosin (H\&E) staining, the histological analysis considered a $0-4$ score grade based on the following parameters: cell influx in the synovial membrane (SM) and cell influx in the periarticular tissue and in the skeletal muscle periarticular tissue.

\section{Time course analysis of the expression of HO-1, TNF- $\alpha$, and IL-1 $\beta$ mRNA in the periarticular tissue and trigeminal ganglion by qRT-PCR}

To study the time course of the genetic expression of HO-1 and its temporal interaction with the HO-1/BVD/CO pathway with the mRNA expression of two of the most important inflammatory mediators-TNF- $\alpha$ and IL- $1 \beta$-we determined the mRNA levels of HO- 1 , TNF- $\alpha$, and IL- $1 \beta$ in the TMJ periarticular tissues and trigeminal ganglion. The qRT-PCR technique was used due to its sensibility and efficiency when analyzing the genetic expression. We used the genes for HO-1, TNF- $\alpha$, IL-1 $\beta$, and GAPDH (housekeeping). Albeit this technique is sensible, this tool needs optimization and normalization procedures for reliable results in each model of study. To guarantee the suitable experimental conditions when applying this technique, primers used for the target genes were developed at the exon-exon junction, not allowing the genomic DNA amplification to occur, which would overestimate the PCR results. In addition, their sequences (Table 1) were designed to obtain a total specificity for the animal species Rattus novergicus albinus, avoiding the amplification of existing contaminants.

\section{Immunohistochemistry analysis of HO-1, TNF-a, and IL-1 $\beta$ in the periarticular tissue and trigeminal ganglion}

Immunohistochemistry for HO- 1 , TNF- $\alpha$, and IL- $1 \beta$ was performed using the streptavidin-biotin (Labelled Streptavidin-Biotin-LSAB) method in formalin-fixed, paraffin embedded tissue sections ( $5 \mu \mathrm{m}$ thick), mounted on glass slides previously prepared with an organosilane-based adhesive (3-aminopropyltriethoxysilane). Briefly, it consisted of the following steps: the sections went through 2 baths in xylol, each lasting ten minutes. After this, they were immersed in three passages of absolute alcohol, then washed in running water, and afterward, a passage in distilled water. Antigen recovery was performed with citrate at $\mathrm{pH}$ 6.0, for $30 \mathrm{~min}$ at $99{ }^{\circ} \mathrm{C}$. After returning to room temperature, the sections were immersed in a $3 \%$ hydrogen peroxide blocking

Table 1 Category and description of primer sequences used according to the National Center for Biotechnology Information (NCBI)

\begin{tabular}{lllll}
\hline Description & Symbol & Sequence & Access number & Amplicon size \\
\hline Heme oxygenase-1 & HO-1 & F 5' ACAGCATACGTAAAGCGTCTCCA-3' & NM_012580.2/NCBI & 136 \\
& & R 5'CATGGCCTTCTGCGCAATCTTCTT-3' & \\
Interleukin-1 beta & IL-1 $\beta$ & F 5'- CCCTGCAGCTGGAGAGTGTGG-3' & NM_031512.2/NCBI \\
& & R 5'- TGTGCTCTGCTTGAGAGGTGCT' & \\
Tumor Necrosis Factor alpha & TNF- $\alpha$ & F 5'- AGAACAGCAACTCCAGAACACCCT-3' & NM_012675.3/NCBI \\
& & R 5'-ATCTCGGATCATGCTTTCCGTGCT-3' & \\
$\begin{array}{l}\text { Glyceraldehyde-3-phosphate } \\
\text { dehydrogenase }\end{array}$ & GAPDH & F 5'-GGGGGCTCTCTGCTCCTCCC-3' & NM_017008.3/NCBI \\
\hline
\end{tabular}


solution for $10 \mathrm{~min}$. After returning to room temperature, the sections were incubated overnight $\left(4{ }^{\circ} \mathrm{C}\right)$ with a primary rabbit anti-HO- 1 , anti-TNF- $\alpha$, and anti-IL- $1 \beta$ antibody (ab13243, ABCAM $^{\circledR}$, England, UK), at the dilution of 1:200, and then washed with a phosphate-buffered saline solution, PBS (phosphate-buffered saline). The samples were incubated with the secondary antibody LSAB Kit for $10 \mathrm{~min}$ at ambient temperature. Next, incubation was performed in a chromogen solution prepared with 3,3' diaminobenzidine (DAB), for $10 \mathrm{~min}$ in a dark chamber. Afterward, the specimens were washed in running water and then in distilled water. Counterstaining was performed with hematoxylin, and afterward, the specimens were dehydrated in alcohol and diaphanized in xylol. Finally, they were mounted on glass slides, which were examined under an optical microscope. The negative control sections were performed, excluding the application of the primary antibody. The parameter of positivity for the immunohistochemical marking of the antigen in all the specimens included in the sample consisted of the cells that exhibited brown staining in their cytoplasm, irrespective of the intensity of the immunomarker.

\section{Pharmacological modulation}

Heme oxygenase/carbon monoxide-biliverdin pathway modulators, hemin (substrate of HO-1/BVD/CO pathway; 0.1, 0.3 or $1 \mathrm{mg} \mathrm{kg}^{-1}$; s.c), DMDC (CO donor; $0.025,0.25$, or 2.5 $\mu \mathrm{Mol} \mathrm{kg}{ }^{-1}$; s.c), ZnPP-IX (specific HO-1 inhibitor; 1, 3 or $9 \mathrm{mg} \mathrm{kg}^{-1}$; s.c), or biliverdin (product of HO-1 pathway; 1,3 or $10 \mathrm{mg} \mathrm{kg}^{-1}$; s.c) were used $60 \mathrm{~min}$ before zymosan $(2 \mathrm{mg})$ injection, except those rats pre-treated with ZnPP-IX or its vehicles, which received a lower dose of zymosan $(1 \mathrm{mg})$. This dose of $1 \mathrm{mg}$ of zymosan was used in rats pre-treated with ZnPP-IX to promote a sub-maximal hypernociception and to allow a possible enhancement of the hypernociception by treatment with the $\mathrm{HO}$ inhibitor. Sham group received saline into left TMJ. Indomethacin $\left(5 \mathrm{mg} \mathrm{kg}^{-1}\right.$, s.c.) was used as a positive control $1 \mathrm{~h}$ before zymosan injection. Furthermore, to analyse the putative involvement of the HO-1/CO/cGMP/ATP-sensitive $\mathrm{K}^{+}$channel pathway, ODQ [an inhibitor of soluble guanylate cyclase (sGC); $12.5 \mu \mathrm{mol}$ $\mathrm{kg}^{-1}$; s.c.] or glibenclamide (an inhibitor of ATP-sensitive $\mathrm{K}+$ channel; $10 \mathrm{mg} \mathrm{kg}^{-1}$; i.p.) was administered $1 \mathrm{~h}$ and 30 min prior to DMDC (2.5 $\mu \mathrm{Mol} \mathrm{kg}^{-1}$; s.c), respectively.

\section{Statistical analysis}

The data are presented as the means \pm S.E.M. or medians, where appropriate. Differences between means were compared using a one-way ANOVA followed by the Bonferroni test. The Kruskal-Wallis test followed by Dunn's test was used to compare medians. A probability value of $P<0.05$ indicated significant differences.

\section{Results}

\section{Effects of hemin, DMDC, biliverdin, or ZnPP-IX on the inflammatory hypernociception and inflammation of zymosan-induced TMJ arthritis}

A 2-mg injection of zymosan resulted in inflammatory hypernociception as measured by a clear decrease in the mechanical threshold of head withdrawal (Fig. 1) $(p<0.05$ vs. Sham). In the intra-articular saline-injected animals (Sham), no significant changes in mechanical withdrawal thresholds were observed. The intra-articular (i.art.) 2-mg injection of zymosan also resulted in a significant increase in the total leukocyte count after 6 h (Fig. 2) $(p<0.05$ vs. Sham). Neutrophils counting rise was determined by the increase in MPO activity in the synovial lavage (Fig. 2) $(p<0.05$ vs. Sham).

To determine whether HO-1 could modulate the inflammatory hypernociception, rats were treated $1 \mathrm{~h}$ before the arthritis induction with the following pharmacological tools: hemin, an HO-1 inducer; DMDC, a CO donor, or biliverdin, the final products of the HO-1/BVD/CO pathway; and ZnPP-IX, specific HO-1 inhibitor. Six hours after the zymosan-induced TMJ arthritis, rats were culled. Figure $1 \mathrm{~A}$ shows a significant increase in the mechanical nociceptive threshold ( $p<0.05$ vs. zymosan) after hemin ( 0.3 and $1 \mathrm{mg} \mathrm{kg}^{-1}$ ). Figure $1 \mathrm{~B}$ shows a significant increase in the mechanical nociceptive threshold ( $p<0.05$ vs. zymosan) after DMDC (0.25 and $\left.2.5 \mu \mathrm{mol} \mathrm{kg}^{-1}\right)$, empha-

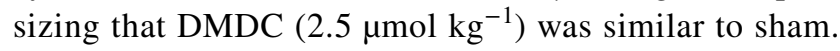
Figure $1 \mathrm{C}$ shows a significant increase in the mechanical nociceptive threshold ( $p<0.05$ vs. zymosan) after biliverdin $\left(1,3\right.$, and $\left.10 \mathrm{mg} \mathrm{kg}^{-1}\right)$ treatments. The anti-nociceptive effects of indomethacin were similar to biliverdin, and it was exceeded by the highest dose of hemin and DMDC treatment, which were similar to the sham group.

Besides, as shown in Fig. 2a, cell infiltration into the TMJ cavity was significantly reduced by hemin $(0.3$ and $1 \mathrm{mg}$ $\mathrm{kg}^{-1}$ ). In Fig. 2b, it is shown that cell infiltration into the TMJ cavity was significantly reduced by DMDC $(0.025$, 0.25 , and $2.5 \mu \mathrm{mol} \mathrm{kg}{ }^{-1}$ ). In addition, in Fig. $2 \mathrm{c}$, cell infiltration into the TMJ cavity was significantly reduced by biliverdin $\left(1,3\right.$, and $\left.10 \mathrm{mg} \mathrm{kg}^{-1}\right)(p<0.05$ vs. zymosan). The MPO activity was also reduced in all the three treatments (Fig. 2E) $(p<0.05$ vs. zymosan). The anti-inflammatory effects of indomethacin were also alike hemin, DMDC, and biliverdin treatments. ZnPP-IX (1, 3, and $9 \mathrm{mg} \mathrm{kg}^{-1}$ ) significantly reduced the mechanical hypernociception threshold, compared to a sub-maximal dose of zymosan $(1 \mathrm{mg})(p<0.05$ vs. zymosan) (Fig. 1d). In addition, ZnPP-IX (3 $\left.\mathrm{mg} \mathrm{kg}^{-1}\right)$ significantly enhanced both the leukocyte count (Fig. 2d) and the MPO activity (Fig. 2f) ( $p<0.05$ vs. zymosan). 

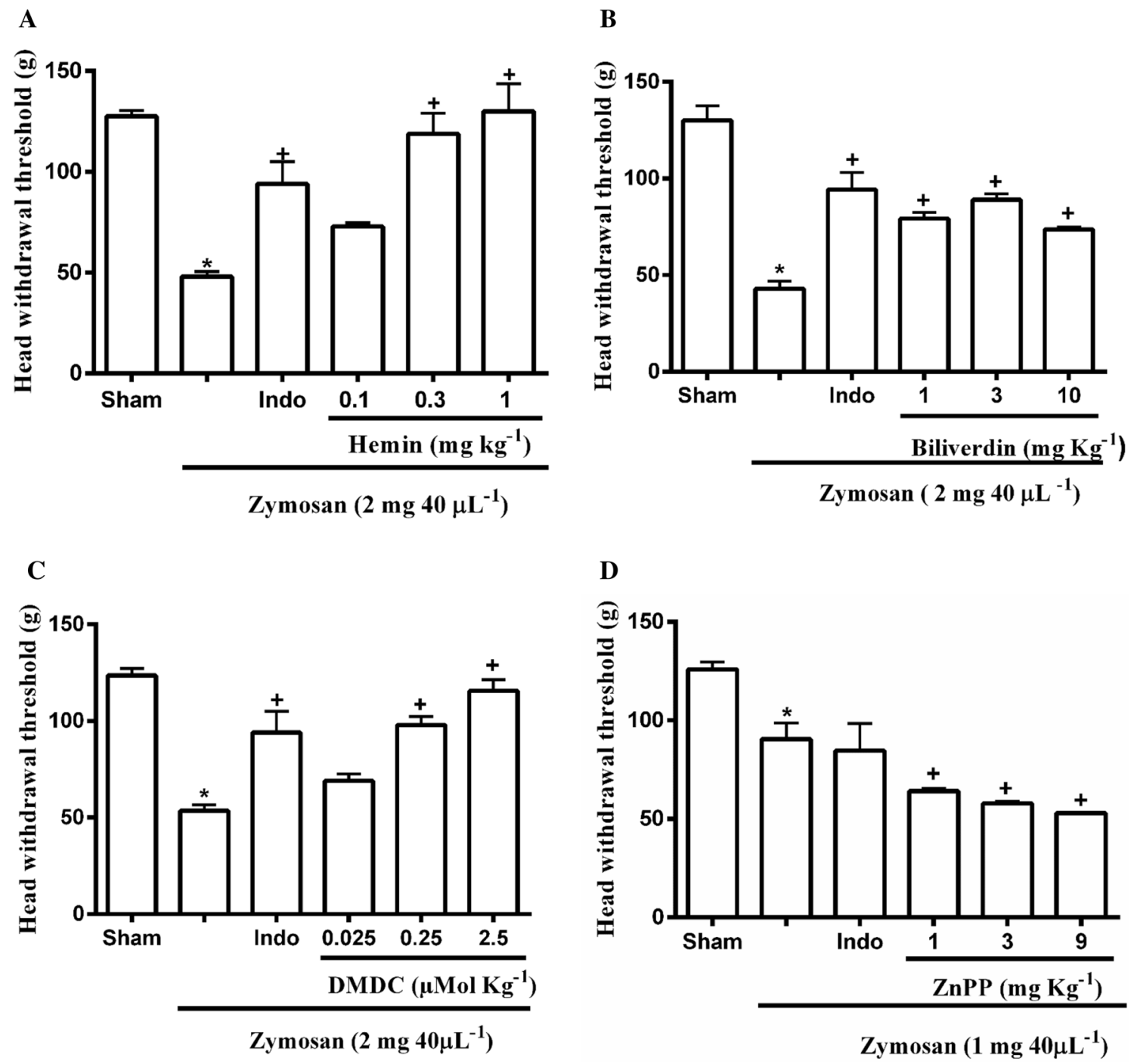

Fig. 1 Effects of hemin, DMDC, biliverdin, and ZnPP on the zymosan-induced hypernociception in the TMJ arthritis. Zymosan ( 1 or $2 \mathrm{mg} ; 40 \mu \mathrm{L}$ ) or saline were injected i.art. into the left TMJ of rats. Hemin $\left(0.1,0.3\right.$, or $\left.1 \mathrm{mg} \mathrm{kg}^{-1}\right)$, DMDC $(0.025,0.25$, or $2.5 \mu \mathrm{mol}$ $\left.\mathrm{kg}^{-1}\right)$, biliverdin $\left(1,3\right.$, or $\left.10 \mathrm{mg} \mathrm{kg}^{-1}\right)$, or $\mathrm{ZnPP}\left(1,3\right.$, or $\left.9 \mathrm{mg} \mathrm{kg}^{-1}\right)$ were injected (s.c.) $60 \mathrm{~min}$ before zymosan. The mechanical nociceptive threshold was measured in hemin (a), DMDC (b), biliverdin

\section{Histopathological analysis}

Six hours after the zymosan-induced TMJ arthritis, inflammatory cell influx was observed in the synovial membrane, the periarticular tissue, the musculoskeletal tissue, and the thickness in synovial membrane (Fig. 3a), compared with the sham group (Fig. 3e). The cell types were predominantly neutrophils, which characterizes acute inflammation.

Edema was also observed in the synovium (Fig. 3a). Histopathological analysis showed that hemin $\left(1 \mathrm{mg} \mathrm{kg}^{-1}\right)$ (Fig. 3b), DMDC (2.5 $\left.\mu \mathrm{mol} \mathrm{kg}^{-1}\right)$ (Fig. 3c), and biliverdin $\left(10 \mathrm{mg} \mathrm{kg}^{-1}\right)$ (Fig. 3d) reduced the inflammatory parameters

(c), and $\mathrm{ZnPP}$-treated animals (d) before and $4 \mathrm{~h}$ after i.art. injection of zymosan or saline. Indomethacin $\left(5 \mathrm{mg} \mathrm{kg}^{-1}\right)$ was used as positive control. Data are expressed as means \pm SEM $(n=6) . * P<0.05$ vs. Sham. ${ }^{+} P<0.05$ vs. zymosan (ANOVA, Bonferroni). $F$ values 1A $F_{(7,40)}=4.254, \mathbf{1 B} F_{(10,50)}=1.312, \mathbf{1 C} F_{(5,29)}=3.258, \quad 1 D$ $F_{(4,25)}=5.518$

to a normal status with a lower inflammatory cell influx into the synovial membrane, the periarticular tissue, the musculoskeletal tissue, and a lower thickness in the synovial membrane was observed. ZnPP-IX ( $3 \mathrm{mg} \mathrm{kg}^{-1}$ ), however, augmented all these parameters, including the thickness of the synovial membrane.

Table 2 shows the scores attributed to TMJ histopathological analysis and compares the values between the sham and the arthritic TMJ groups. In addition, it was compared the values between the arthritic TMJ and the arthritic TMJ treated with hemin $\left(1 \mathrm{mg} \mathrm{kg}^{-1}\right)$, DMDC $\left(2.5 \mu \mathrm{mol} \mathrm{kg}^{-1}\right)$, and biliverdin $\left(10 \mathrm{mg} \mathrm{kg}^{-1}\right)$. A significant 

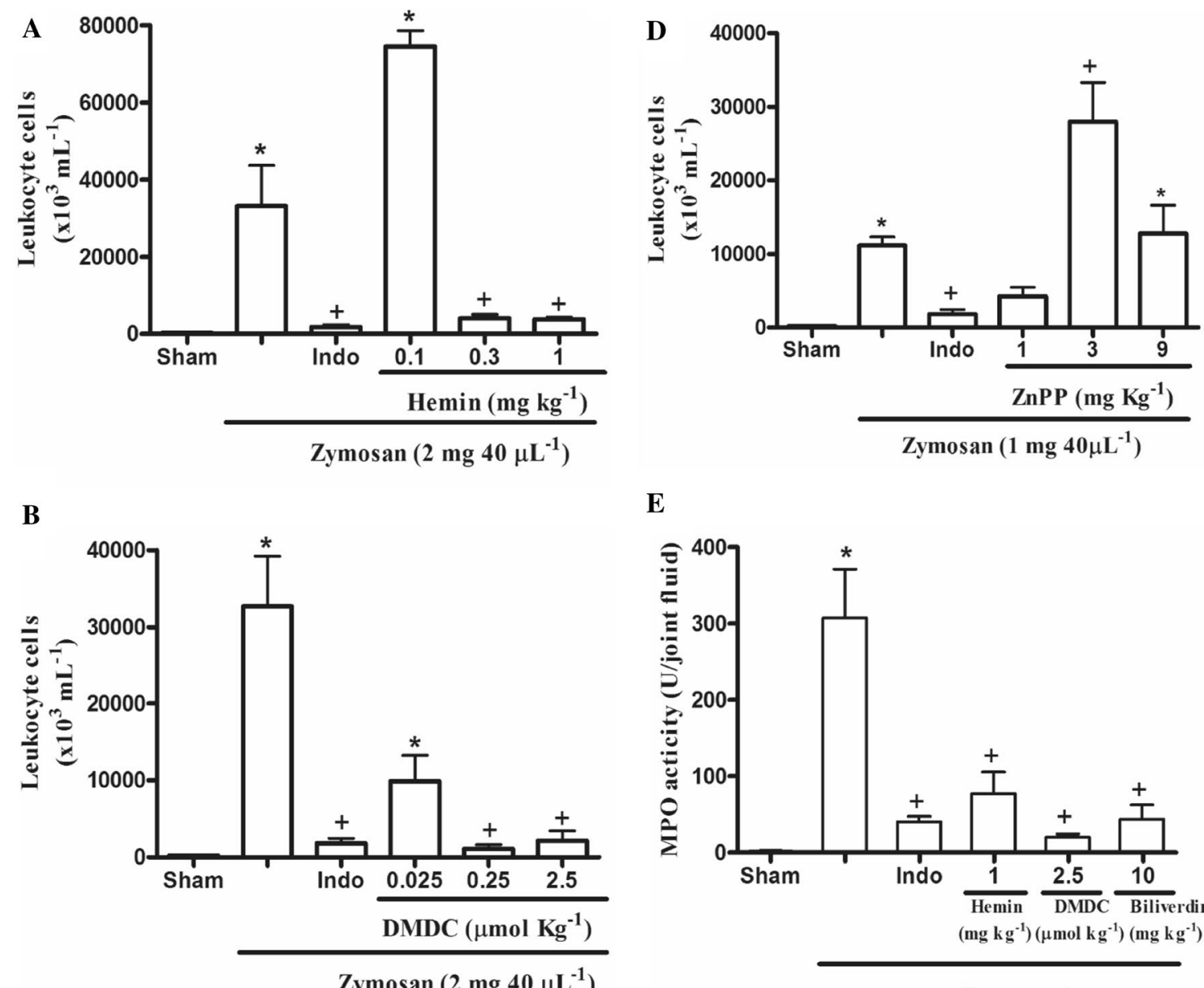

$\mathbf{E}$
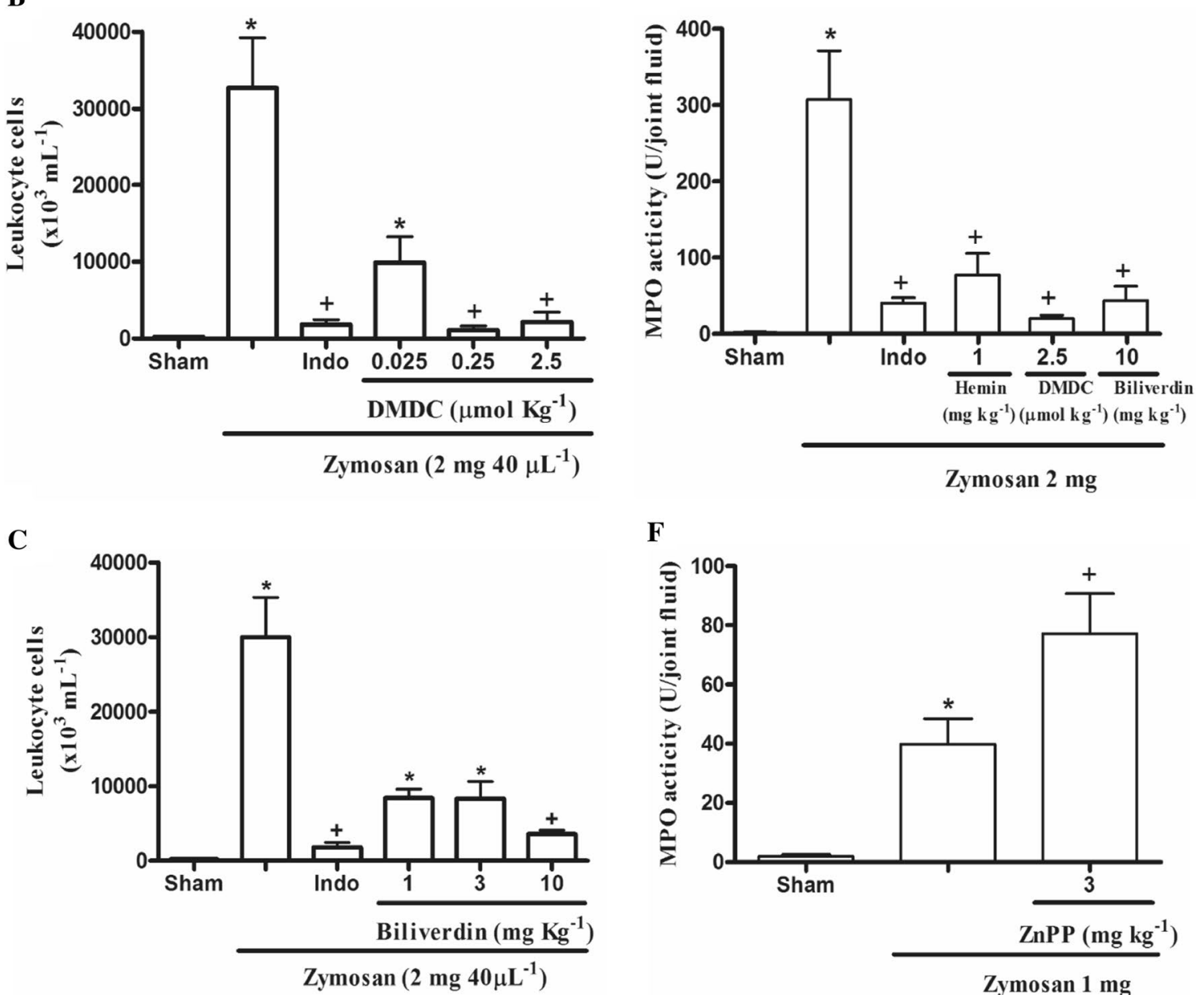

$\mathbf{F}$

Fig. 2 Effects of indomethacin, hemin, DMDC, biliverdin, and ZnPP on leukocyte cell numbers and MPO activity. Zymosan (1 or $2 \mathrm{mg}$; $40 \mu \mathrm{L})$ or saline was injected i.art. into the left TMJ rats. Hemin $(0.1$, 0.3 , or $\left.1 \mathrm{mg} \mathrm{kg}^{-1}\right)$, DMDC $\left(0.025,0.25\right.$, or $\left.2.5 \mu \mathrm{mol} \mathrm{kg}{ }^{-1}\right)$, Biliverdin $\left(1,3\right.$ or $\left.10 \mathrm{mg} \mathrm{kg}^{-1}\right)$, or ZnPP $\left(1,3\right.$ or $\left.9 \mathrm{mg} \mathrm{kg}^{-1}\right)$ were injected (s.c.) $60 \mathrm{~min}$ before zymosan. After $6 \mathrm{~h}$, leukocyte migration was evaluated in Hemin (a), DMDC (b), Biliverdin (c), and ZnPP-treated

animals (d) by cell counting in TMJ synovial lavage. MPO activity was measured in TMJ synovial lavage in Hemin-, DMDC-, Biliverdin (e) and ZnPP-treated animals (f). Indomethacin $\left(5 \mathrm{mg} \mathrm{kg}^{-1}\right)$ was used as positive control. Data are expressed as means \pm SEM $(n=6)$. $* P<0.05$ vs. Sham. ${ }^{+} P<0.05$ vs. zymosan (ANOVA, Bonferroni). $F$ values 2A $F\left({ }_{6,27}\right)=5.830,2 \mathbf{B} F_{(5,33)}=6.716,2 \mathrm{C} \mathrm{F}_{(5,25)}=4.222, \mathbf{2 D}$ $F_{(5,26)}=2.999, \mathbf{2 E} F_{(5,25)}=3.584, \mathbf{2} \mathbf{F} F_{(2,13)}=2.212$ 


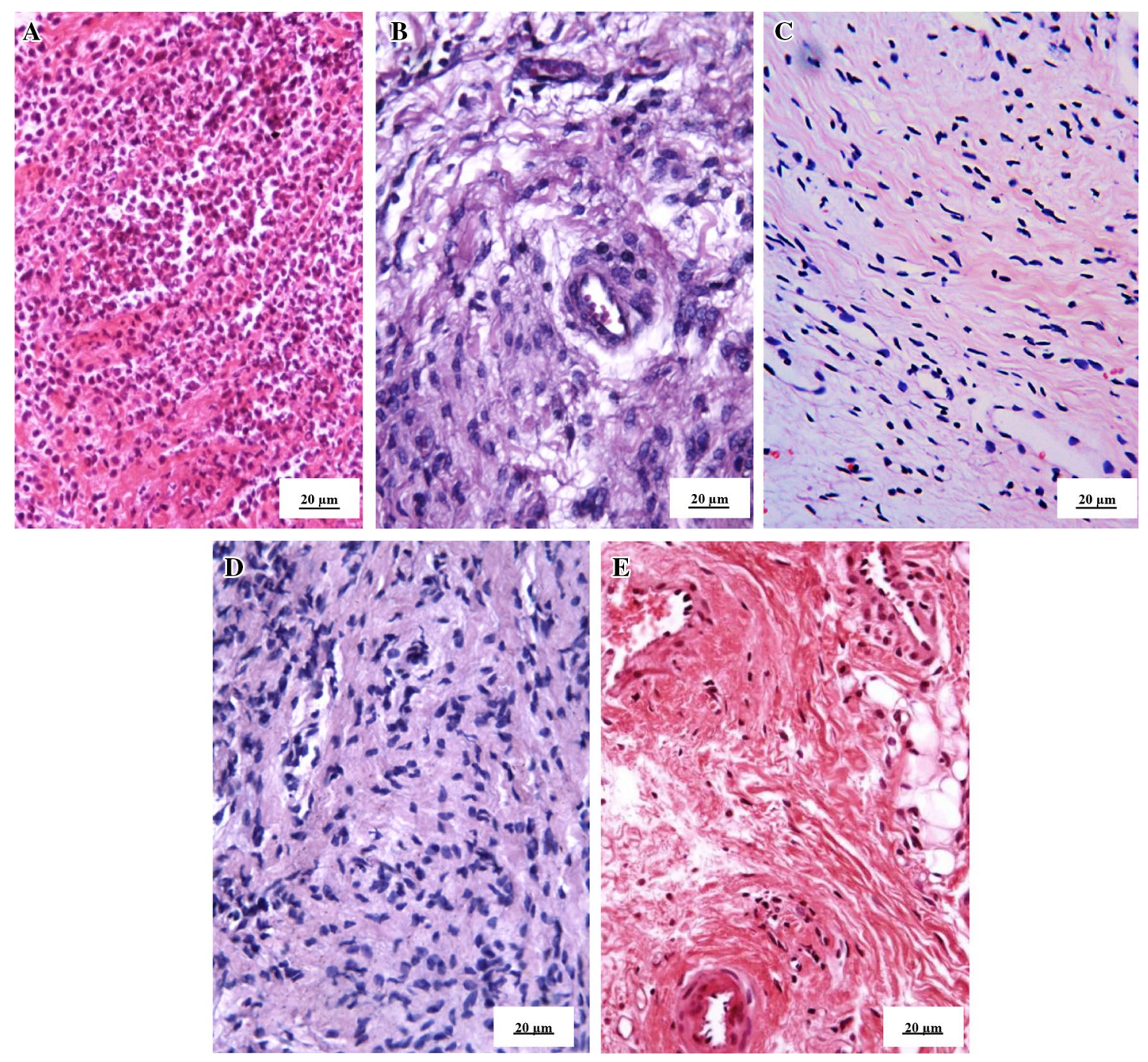

Fig. 3 Temporomandibular joint histopathological analysis. Photomicrographs of the TMJ of zymosan group (A) and hemin $\left(1 \mathrm{mg} \mathrm{kg}^{-1}\right)$, DMDC $(2.5 \mu \mathrm{mol} / \mathrm{kg})$, and biliverdin $(10 \mathrm{mg} / \mathrm{kg})$-treated animals (bd) and sham animals (e). a Arthritic rats, induction by zymosan $2 \mathrm{mg}$ showing inflammatory cell influx into the synovial membrane, periarticular tissue, musculoskeletal tissue, and synovial membrane thick- ness $(400 \times)$, b TMJ of arthritic rats injected with zymosan $2 \mathrm{mg}$ and treated with hemin $1 \mathrm{mg} \mathrm{kg}^{-1}(400 \times)$, c TMJ of arthritic rats injected with zymosan $2 \mathrm{mg}$ treated with DMDC $2.5 \mu \mathrm{mol} \mathrm{kg}{ }^{-1}(400 \times)$, d TMJ of arthritic rats injected with zymosan $2 \mathrm{mg}$ treated with Biliverdin $10 \mathrm{mg} \mathrm{kg}^{-1}$, and e TMJ of sham animals injected with $40 \mu \mathrm{L}$ of saline solution $(400 \times)$. Hematoxylin and eosin staining
Table 2 Histopathological analysis of TMJ: the effects of $\mathrm{HO}-1 / \mathrm{CO} / \mathrm{BVD}$ pathway modulators

\begin{tabular}{lccc}
\hline & $\begin{array}{l}\text { Cell influx into the synovial } \\
\text { membrane }\end{array}$ & $\begin{array}{l}\text { Periarticular cell } \\
\text { influx }\end{array}$ & $\begin{array}{l}\text { Cell influx into } \\
\text { the muscular } \\
\text { tissue }\end{array}$ \\
\hline Sham & $0(0-0)$ & $0(0-0)$ & $0(0-0)$ \\
Zymosan $2 \mathrm{mg}$ & $2.5(1-3)^{*}$ & $4(4-4)^{*}$ & $3(2-4)^{*}$ \\
Hemin $1 \mathrm{mg} \mathrm{kg}$ & $1(0-2)^{+}$ & $1.5(1-3)^{+}$ \\
DMDC $2.5 \mu \mathrm{mol} \mathrm{kg}^{-1}$ & $0.5(0-1)^{+}$ & $2.5(1-4)^{+}$ & $1.5(1-3)^{+}$ \\
Biliverdin $10 \mathrm{mg} \mathrm{kg}^{-1}$ & $1(1-2)^{+}$ & $1(0-2)^{+}$ & $1(0-2)^{+}$ \\
Zymosan $1 \mathrm{mg}$ & $1(0-2)^{+}$ & $4(2-4)^{*}$ & $1(1-2)^{*}$ \\
ZnPP 3 mg/kg & $2(2-2)^{*}$ & $4(4-4)^{*}$ & $3.5(3-4)^{+}$ \\
\hline
\end{tabular}

$* p<0.05$ vs. Sham

${ }^{+} p<0.05$ vs. zymosan (Kruskal-Wallis, Dunn's) 
Fig. 4 Effects of the inhibition of cGMP synthesis and the potassium channel blockage in the zymosan-induced TMJ arthritis. Zymosan ( $2 \mathrm{mg} ; 40 \mu \mathrm{L}$ ) or saline was injected i.art. into the left TMJ of rats. ODQ (12.5 $\mu \mathrm{mol} \mathrm{kg}{ }^{-1}$; s.c.) or glibenclamide (10 $\mathrm{mg} \mathrm{kg}^{-1}$; i.p.) was administered $1 \mathrm{~h}$ and $30 \mathrm{~min}$ prior to DMDC (2.5 $\mu \mathrm{Mol} \mathrm{kg}{ }^{-1}$; s.c), respectively. ODQ and glibenclamide, prior to DMDC, reverted the mechanical nociceptive threshold on the 4 th $\mathrm{h}$ after i.art. injection of zymosan (a), the leukocyte migration (b), and the MPO activity from TMJ synovial lavage (c), both on the 6th $\mathrm{h}$ after i.art. zymosan injection. Data are expressed as means \pm SEM $(n=6) .{ }^{*} P<0.05$ vs. Sham or DMDC $(2.5 \mu \mathrm{Mol} / \mathrm{Kg}$ ) (ANOVA, Bonferroni). $F$ values $4 \mathrm{~A}$ $F_{(4,25)}=2.474,4 \mathrm{~B} F_{(4,22)}=2.930,4 \mathrm{C} F_{(4,57)}=3.865$

( $p<0.05$ vs. Sham) increase in the inflammatory parameters was observed in the arthritic TMJ group. A significant ( $p<0.05$ vs. zymosan) reduction in the inflammatory parameters was observed in all the treated groups with with hemin $\left(1 \mathrm{mg} \mathrm{kg}^{-1}\right)$, DMDC $\left(2.5 \mu \mathrm{mol} \mathrm{kg}{ }^{-1}\right)$, and biliverdin (10 $\left.\mathrm{mg} \mathrm{kg}^{-1}\right)$. ZnPP-IX (3 $\left.\mathrm{mg} \mathrm{kg}^{-1}\right)$, however, enhanced the cell influx into the synovial membrane, the periarticular tissue and the muscular tissue $(p<0.05$ vs. zymosan).

\section{Effects of the inhibition of cGMP synthesis and the ATP-sensitive $\mathrm{K}^{+}$channel blockage on the inflammatory hypernociception of zymosan-induced TMJ arthritis}

To determine whether the inhibition of soluble guanylate cyclase (sGC) generating cGMP and the blockage of the ATP-sensitive $\mathrm{K}^{+}$channel affect the anti-nociceptive and anti-inflammatory effect of the via HO-1/CO, ODQ (an inhibitor of sGC) or glibenclamide (an inhibitor of ATPsensitive $\mathrm{K}^{+}$channel) was administered $1 \mathrm{~h}$ or $30 \mathrm{~min}$ prior to DMDC, respectively, to analyse the participation of the $\mathrm{HO}-1 / \mathrm{CO} / \mathrm{cGMP} / \mathrm{ATP}$-sensitive $\mathrm{K}^{+}$channel pathway on the inflammatory hypernociception in the zymosaninduced TMJ arthritis.

Figure 4a shows a significant reduction in the mechanical nociceptive threshold ( $\mathrm{p}<0.05$ vs. DMDC) after ODQ and glibenclamide treatments prior to DMDC, revealing that the anti-nociceptive effect of the DMDC depends from sGC and ATP-sensitive $\mathrm{K}^{+}$channel. The inflammatory hypernociception of the ODQ and the glibenclamide groups was similar to the zymosan group. Figure $4 \mathrm{~b}$ shows a significant reduction in the leucocyte influx ( $p<0.05$ vs. DMDC) after ODQ and glibenclamide treatments prior to DMDC, revealing that the anti-inflammatory of the DMDC effect depends from sGC and ATP-sensitive $\mathrm{K}^{+}$ channel. The leucocyte influx of the ODQ and the glibenclamide groups was also similar to the zymosan group. This was corroborated by MPO activity that was significantly reverted to a similar condition of the zymosan group ( $p<0.05$ vs. DMDC) (Fig. 4c).
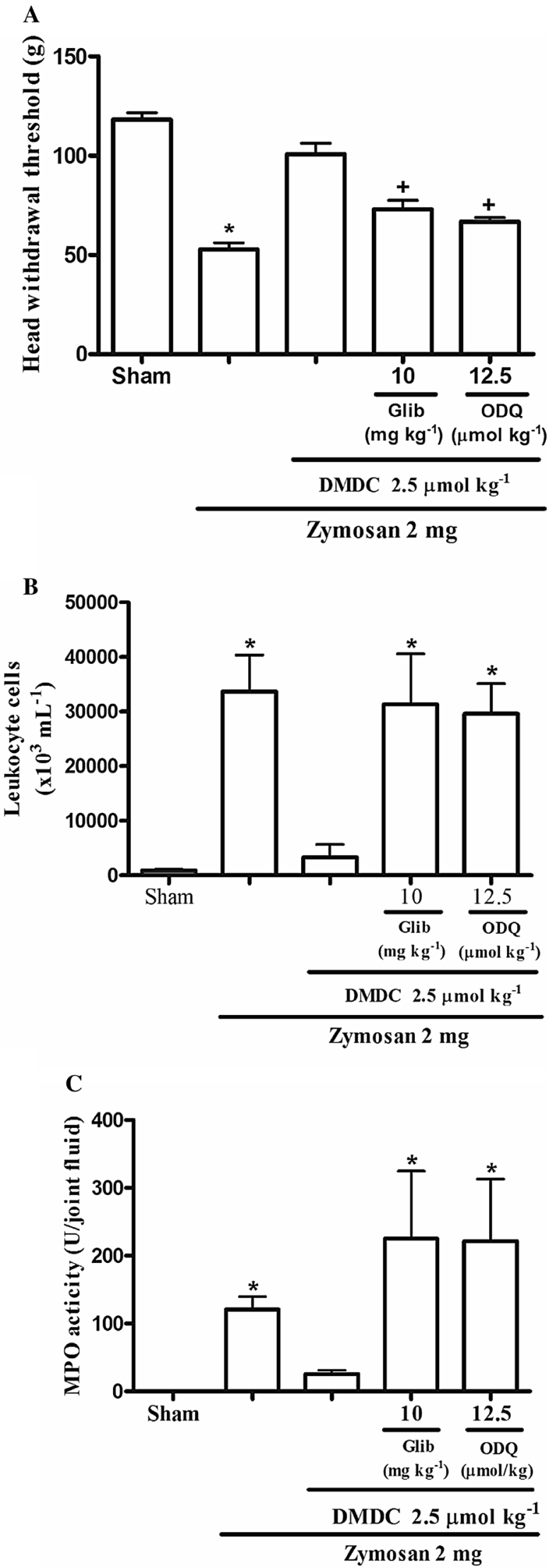


\section{Time course analysis of the expression of $\mathrm{HO}-1$, TNF- $\alpha$, and IL-1 $\beta$ mRNA in the periarticular tissue and trigeminal ganglion by qRT-PCR}

It can be observed a significant increase $(p<0.05)$ in the HO- 1 relative gene expression in the rat TMJ from hours 6 to 24 after the zymosan injection $(2 \mathrm{mg})$, peaking at hour 9 when compared with sham group (Fig. 5a). In the trigeminal ganglion, the HO-1 relative expression significantly increased $12 \mathrm{~h}$ after the intra-articular injection of $2 \mathrm{mg}$ of zymosan $(p<0.05)$ in comparison with the sham group (Fig. 5b).

There is also a significant relative gene expression enhancement of TNF- $\alpha$ in the rat TMJ from hours 3 to 24 after the zymosan injection $(p<0.05)$; this expression peaked at hour 9 when compared with the sham group (Fig. 5c). In the trigeminal ganglion, the TNF- $\alpha$ gene expression consistently increased from hours 6 to 12 after the zymosan injection in comparison with the sham group (Fig. 5d).

Regarding the relative gene expression of IL-1 $\beta$, it can be observed a rise in the IL- $1 \beta$ mRNA levels in the rat TMJ from hours 3 to 24 after the injection of zymosan, peaking at hour 9 in comparison with the sham group $(p<0.05)$ (Fig. 5e). In the trigeminal ganglion, a significant increase $(p<0.05)$ in the relative gene expression of IL- $1 \beta$ is observed from hour 6 after zymosan injection, peaking at hour 12 compared with the sham group (Fig. 5f).

\section{Immunohistochemical analysis for HO-1, TNF-a, and IL-1 $\beta$ in the periarticular tissue and trigeminal ganglion}

Immunohistochemical analysis showed increased HO-1 expression characterized by brown-colored cells in the TMJ of arthritic rats (Fig. 6b-d). The cell types which expressed HO-1 were chondrocytes (Fig. 6b), neutrophils (Fig. 6c), and synovial cells (Fig. 6d). The negative control group sections consisted of zymosan-induced TMJ samples that were not incubated with anti- HO-1 antibody (Fig. 6a). The sham group is observed a light expression of HO-1 (Fig. 6e). Regarding the HO-1 immunohistochemical analysis in the rat trigeminal ganglion $12 \mathrm{~h}$ after the zymosan injection, it can be observed a rise in the HO-1 expression (Fig. 6g) in comparison with control (Fig. 6e) and sham animals (Fig. 6f). This can be observed through an intense brown coloring of the cells. Arthritic animals show a cellular immunolabeling for HO-1 that is identified either in the neuronal body (green arrow) and in the glial cells (white arrow) (Fig. 6g).

At the immunohistochemical analysis of the TNF- $\alpha$ expression, it can be observed a slightly increase in this cytokine immunolabeling in arthritic rats (Fig. 7c, d) compared with the sham animals (Fig. 7a, b). In arthritic animals, the TNF- $\alpha$ immunolabeling occurred in chondrocytes (Fig. 7c), synovial cells, and neutrophils (Fig. 7d). Furthermore, the TNF- $\alpha$ immunohistochemical expression in the rat trigeminal ganglion $12 \mathrm{~h}$ after the zymosan injection shows a mild rise in this cytokine expression in this neural structure (Fig. 7f), compared with the sham group (Fig. 7e). This can be observed through an intense brown coloring of the cells. Like the HO-1 expression, the TNF- $\alpha$ immunolabeling was identified in the neuronal body (green arrow) and glial cells (white arrow).

The immunohistochemical analysis of the IL- $1 \beta$ expression shows a noticeable increase of this cytokine expression in the TMJ of the arthritic rats (Fig. 8b, c) in comparison with sham animals (Fig. 8a). The IL-1 $\beta$ immunolabeling was identified in chondrocytes (Fig. 8b), synovial cells, and neutrophils (Fig. 8c) of the arthritic rats. In addition, it can be observed that the IL-1 $\beta$ immunolabeling in neutrophils is more intense than the TNF- $\alpha$ one. In relation with the $\mathrm{IL}-1 \beta$ expression in the rat trigeminal ganglion $12 \mathrm{~h}$ after the zymosan injection, it is noticeable a very intense immunolabeling for this cytokine in arthritic animals (Fig. 8e) compared with the sham group (Fig. 8d). Resembling the HO-1 and TNF- $\alpha$ expression, the IL- $1 \beta$ expression was observed in the the neuronal body (green arrow) and glial cells (white arrow) (Fig. 8e) of the zymosan group animals.

\section{Discussion}

Heme oxygenase (HO) activity is known to down-regulate inflammatory events. Here, we address the role of $\mathrm{HO}$ and its metabolites, carbon monoxide (CO), and biliverdin (BVD), in the zymosan-induced temporomandibular joint (TMJ) arthritis in rats. In addition, we found evidence that $\mathrm{HO} /$ CO pathway acts, at least in part, on cGMP and ATP-sensitive $\mathrm{K}^{+}$channel-dependent mechanisms, downregulating hypernociception during temporomandibular joint arthritis. Our data provide the first evidence that pharmacologically induced up-regulation of HO-1 triggers a robust protective anti-inflammatory response in the TMJ arthritis.

Over the last few years, numerous studies have demonstrated that HO-1 expression and the concomitant production of its metabolites, $\mathrm{CO}$ and BVD, have anti-nociceptive and anti-inflammatory consequences [16, 18, 21, 23-28]. In a zymosan-induced air pouch inflammation model, hemin administration increased both HO-1 expression and activity, which were associated with bilirubin production and antiinflammatory outcomes-reduction in leukocyte migration, exudation, and pro-inflammatory mediator release [20]. It is known that HO-1 induction in microvascular endothelial cells confers resistance to oxidative stress and inhibits up-regulation of adhesion molecules, resulting in decreased 

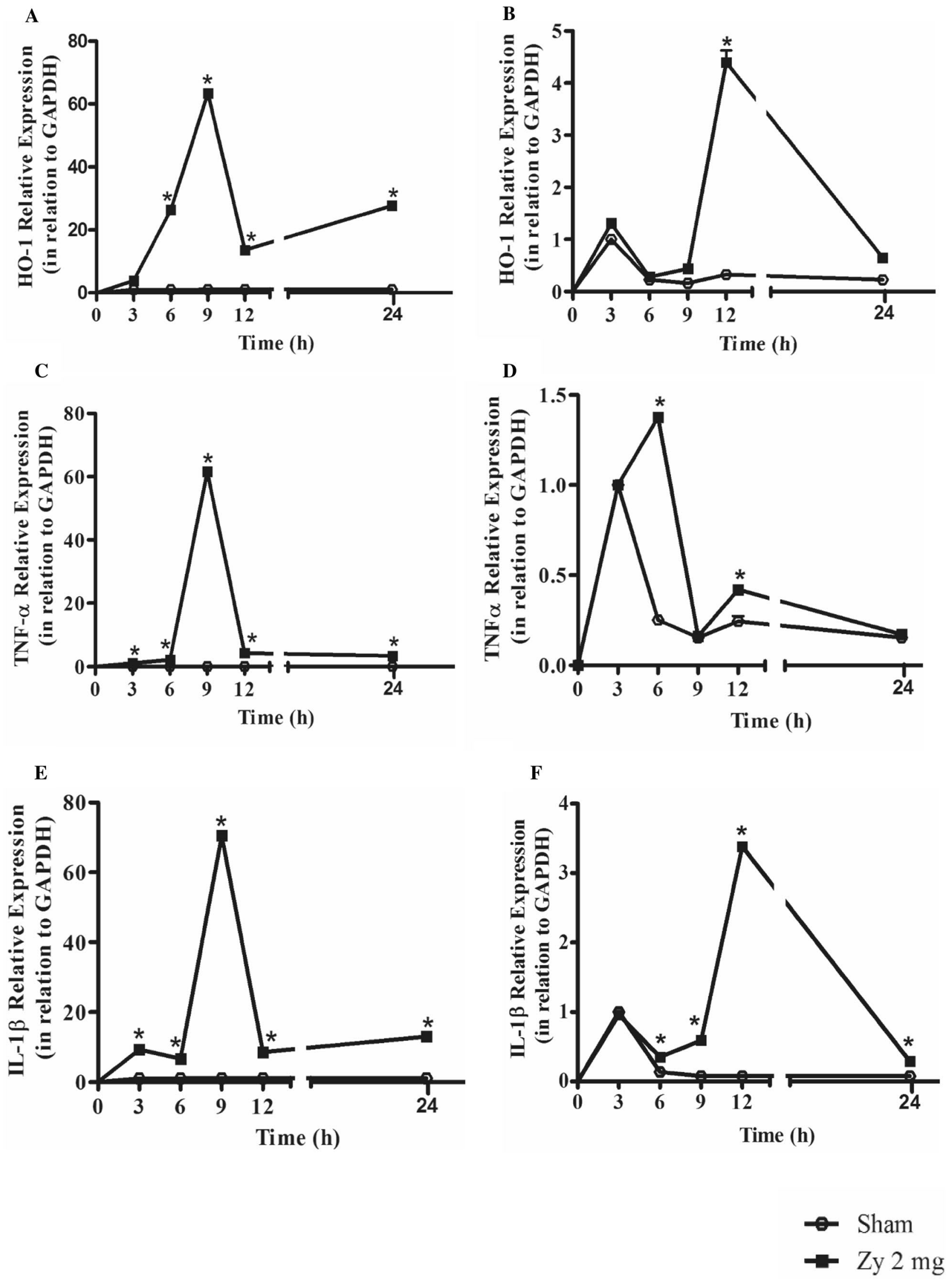
४Fig. 5 Time course of the relative gene expression of HO-1, TNF$\alpha$, and IL-1 $\beta$ in the TMJ periarticular tissue and trigeminal ganglion of rats after zymosan injection $(2 \mathrm{mg} ; 40 \mu \mathrm{L})$ into the temporomandibular joint. After sacrifice, the left TMJ periarticular tissue and the trigeminal ganglion were excised and processed for qRT-PCR. There is a rise in the relative gene expression of HO-1 from the 6th hour in the TMJ (a) and at the 12th hour in the trigeminal ganglion (b). $\mathrm{TNF}-\alpha$ relative gene expression increases from the 3rd hour, peaking at the 9th hour in the TMJ (c). In the trigeminal ganglion, it peaks at the 6th and 12 th hours (d). The IL-1 $\beta$ relative gene expression shows similar patterns-there is an increase in its expression from the 3rd hour, peaking at the 9th hour in the TMJ (e) and it peaks at the 6th and 12th hours in the trigeminal ganglion (f). All the calculations were carried out by the $2-{ }^{\Delta \Delta C \mathrm{t}}$ method. $* P<0.05$ in relation with sham groups (ANOVA, Bonferroni). $F$ values $\mathbf{5 A} F_{(5,12)}=2.892$, 5B $F_{(6,14)}=2.488, \quad 5 C \quad F_{(5,12)}=1.472, \quad 5 D \quad F_{(6,14)}=1.788, \quad \mathbf{5 E}$ $F_{(5,12)}=0.9496, \mathbf{5 F} F_{(6,14)}=1.471$

leukocyte recruitment [29]. In this context, the control of inflammatory responses by HO- 1 could be related to inhibitory effects on P- and E-selectin expression in vascular endothelial cells mediated by the antioxidant molecules biliverdin or bilirubin [30].

In this regard, we demonstrated that HO-1 induction by both hemin and biliverdin, the final products of the HO-1 pathway, suppressed the development of inflammation and hypernociception in the TMJ arthritis. Based on these results, we can propose that the action of HO-1 in the TMJ arthritis is, at least in part, mediated by decreasing neutrophils recruitment, since hemin or biliverdin administration was associated with leukocyte count reduction and MPO activity in the synovial lavage of the TMJ. Histological features corroborate with these data, also showing a reduction of acute inflammation in the synovial membrane, in the periarticular tissue and in the musculoskeletal tissue.

Our data are in accordance with the previous findings [31], which showed a protective anti-inflammatory response of the HO-1 up-regulation in a model of non-autoimmune arthritis in mice. In chronic experimental models of arthritis, however, it was observed a dual effect of HO-1, since induction of HO-1 resulted in inhibition of cartilage erosion and reduction in joint fibrosis, while HO-1 inhibition reduced joint inflammation, cartilage destruction, leukocyte infiltration, hyperplasic synovitis, erosion of articular cartilage and osteolysis, as well as, the production of inflammatory mediators [32, 33]. The involvement of HO-1 in chronic conditions, thus, needs further investigation, especially in chronic TMJ arthritis, since it has been proposed that during chronic inflammation HO-1 would exert an anti-inflammatory action by inhibiting leukocyte infiltration as well as by facilitating tissue repair through vascular endothelial growth factor (VEGF)-driven angiogenesis [34].

It is known that the anti-inflammatory effects of HO-1 depend on the biochemical properties of heme degradation products, namely, CO, ferritin, and BVD [16]. We have recently found evidence that the molecular cascade formed by $\mathrm{HO} / \mathrm{CO} / \mathrm{BVD}$ reduced nociception during an acute inflammatory reaction [26]. Kobayashi et al., 2006 [35] reported that $\mathrm{CO}$, but not $\mathrm{Fe}^{2+}$ nor BVD, was responsible for the suppressive effects of endogenously expressed or chemically induced HO-1 on cytokine synthesis. It was also demonstrated that $\mathrm{HO} / \mathrm{CO}$ pathway plays an anti-nociceptive role during carrageenan-evoked inflammation and that $\mathrm{CO}$ is the HO product involved in the evoked antinociception [36]. In accordance with these previous findings, our present study demonstrated that inflammatory hypernociception was reduced by DMDC, a CO donor. Furthermore, we observed that treatment with ZnPP-IX, a specific inhibitor of HO-1, potentiates the inflammatory hypernociception induced by a sub-maximal dose of zymosan.

Most of CO action has been reported to be dependent on both the activation of sGC activity and the subsequent increases in cGMP levels [15, 37]. These biochemical effects result in a reduced production of pro-inflammatory cytokines (IL-1, TNF $\alpha$, IL-6, and IL-8) and enhanced synthesis of the anti-inflammatory cytokine IL-10 [35, 38]. The HO/ $\mathrm{CO} / \mathrm{cGMP}$ pathway has been reported to be involved in the peripheral and the spinal modulation of both inflammatory and non-inflammatory pain [36, 39-41]. Besides, it is known that elevated levels of cGMP are associated with nociceptor hypersensitivity inhibition [42, 43], and pharmacological evidence suggested that cGMP may increase $\mathrm{K}^{+}$conductance by opening ATP-sensitive $\mathrm{K}^{+}$channel directly or indirectly via protein kinase $\mathrm{G}$ [44]. The present data are consistent and it is the first study to base the notion that the $\mathrm{HO} / \mathrm{CO} /$ cGMP/ATP-sensitive $\mathrm{K}^{+}$channel pathway can modulate the inflammatory hypernociception during the zymosan-induced TMJ arthritis and could be a possible molecular target for pharmacological modulation, but more assays are required as only a CO donor was tested against.

To date, HO-1 protein was highly expressed in synoviocytes, infiltrating inflammatory lymphocytes, and endothelial cells of synovial tissue, in chondrocytes and in peripheral blood mononuclear cells from patients with rheumatoid arthritis and osteoarthritis, and both synovial tissues and chondrocytes have been reported to produce inflammatory cytokines which were reduced by up-regulation of the HO-1 system [35, 38, 45-47]. In fact, within inflamed joints, a plethora of cells are potential sources of HO-1, including synoviocytes, chondrocytes, and mast cells, as well as infiltrating neutrophils and monocytes.

In the present study, immunohistochemical analysis showed increasing HO-1 expression in synoviocytes, chondrocytes, and neutrophils of zymosan arthritic TMJ, suggesting that these cells are probably involved in the synthesis of cytokines and may be modulated by the HO-1/BVD/ $\mathrm{CO}$ pathway. Moreover, we observed that HO-1 was lightly expressed in TMJ tissues without arthritis. In this regard, in the normal TMJ, we also showed the physiological presence 

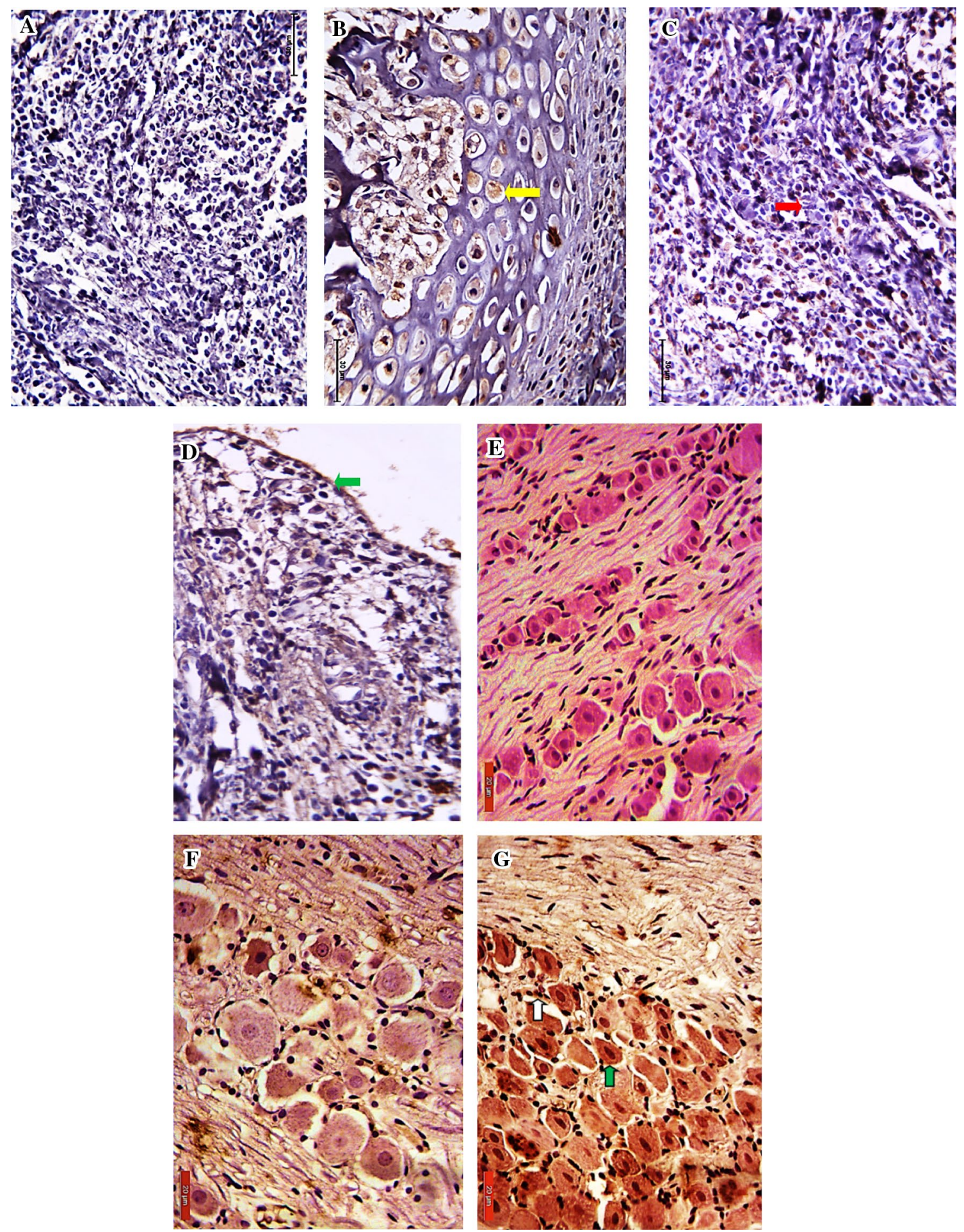

Fig. 6 Immunostaining for $\mathrm{HO}-1$ in the temporomandibular joint and trigeminal ganglion of arthritic animals after zymosan injection. Animals were sacrificed $6 \mathrm{~h}$ after the zymosan injection and the temporomandibular joint was removed for immunohistochemical analysis. Negative control (sections in the absence of anti-HO-1 antibody) (a) in the arthritic rats. TMJ arthritis induced by $2 \mathrm{mg}$ of zymosan showing strong immunostaining for HO-1 in chondrocytes (b), neutro- phils (c), and synoviocytes (d) (400x). For the immunohistochemical analysis of HO-1 in the trigeminal ganglion, animals were sacrificed $12 \mathrm{~h}$ after the zymosan injection. e Negative control control (sections in the absence of anti-HO-1 antibody), $\mathbf{f}$ sham group, and $\mathbf{g}$ zymosan group showing intense brown coloring for HO-1 in the neuronal body (green arrow) and glial cells (white arrow) (400×) 

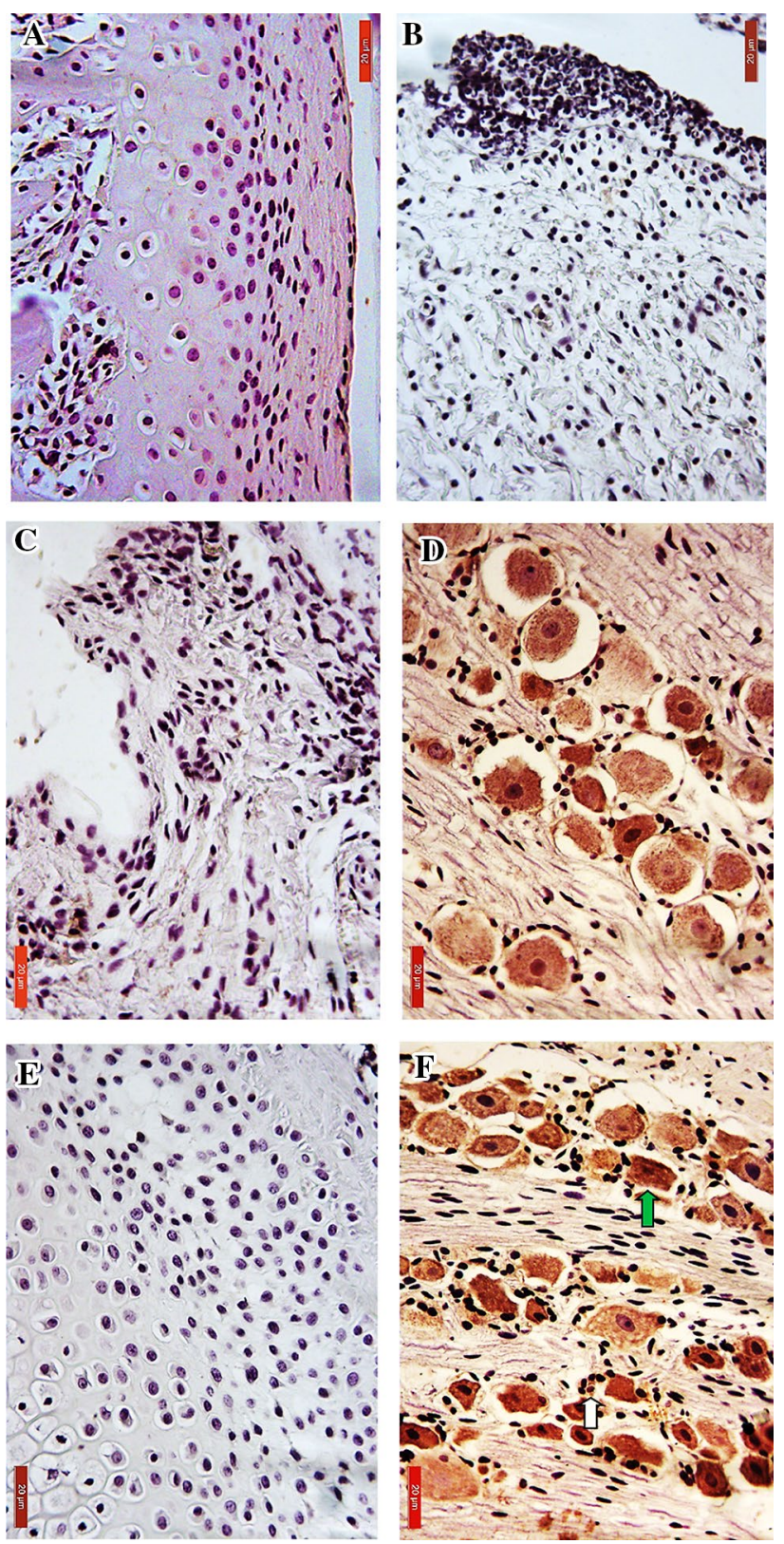

Fig. 7 Immunostaining for TNF- $\alpha$ in the temporomandibular joint and trigeminal ganglion of arthritic animals after zymosan injection. Animals were sacrificed $6 \mathrm{~h}$ after the zymosan injection and the temporomandibular joint was removed for immunohistochemical analysis. Negative control (sections in the absence of an anti-TNF- $\alpha$ antibody) a, b sham group. c, d Arthritic rat TMJ showing slightly TNF- $\alpha$ immunolabeling in chondrocytes (c), neutrophils, and synoviocytes (d) $(400 \times)$. For the immunohistochemical analysis of TNF- $\alpha$ in the trigeminal ganglion, animals were sacrificed $12 \mathrm{~h}$ after the zymosan injection. e Sham group, and $\mathbf{f}$ zymosan group showing slightly TNF- $\alpha$ immunolabeling in the neuronal body (green arrow) and glial cells (white arrow) $(400 \times)$

of iNOS in synoviocytes and chondrocytes [7]. Accordingly, HO-1 may also play an important role in the physiological maintenance of the TMJ. In addition, we showed that the
$\mathrm{HO} / \mathrm{CO} / \mathrm{cGMP} / \mathrm{ATP}$-sensitive $\mathrm{K}^{+}$channel pathway modulates the inflammatory hypernociception in the zymosaninduced TMJ arthritis.

Regarding the cytokine expression, TNF- $\alpha / \mathrm{IL}-1 \beta$ mRNA expression rose over time and the immunohistochemical analysis showed markedly cytokine expression. It was observed that the increase in the cytokine levels preceded the peak pain, which reinforce that pro-inflammatory cytokines play an important role in the pathophysiology of pain as inflammatory stimuli or tissue injuries stimulate the release of characteristic cytokine cascades, which ultimately trigger the release of final mediators responsible for inflammatory pain. These final mediators, such as prostanoids or sympathetic amines, act directly on the nociceptors to cause hypernociception, which results from the lowering of the threshold due to modulation of specific voltage-dependent sodium channels [48, 49].

In addition, pro-inflammatory cytokines, including tumor necrosis factor TNF- $\alpha$ and IL- $1 \beta$, play a crucial role in the pathogenesis of arthritis, increasing the recruitment of neutrophils into the joint and driving the enhancement of chemokines and degradative enzymes production $[50,51]$. In addition, elevated levels of TNF- $\alpha$ in the capsule of the temporomandibular joint are implicated in the underlying pathology of temporomandibular disorders [52].

Moreover, HO-1 can be modulated by cytokines, since the pro-inflammatory cytokines IL- $1 \beta$ and TNF- $\alpha$ down-regulate this protein, whereas the anti-inflammatory cytokine IL-10 opposes such effect [53-55]. In addition, the suppression of endogenously expressed HO-1 results in significant enhancement of spontaneous TNF- $\alpha$ and LPS-induced IL-6 and IL-8 synthesis, whereas HO-1 induction leads to reduced synthesis of the pro-inflammatory cytokines and COX-2 expression [35]. Our results thus provide evidence that elevated levels of IL- $1 \beta$ and TNF- $\alpha$ in the periarticular tissues and trigeminal ganglion promotes nociception, suggesting that, following the HO-1 inhibition, the levels of these inflammatory cytokines rise to enhance the TMJ inflammatory hypernociception. In addition, the protective role of HO-1 explains why its mRNA levels did not coincide with pain peak, because a protective response is more likely to be mounted after noxious stimuli have occurred.

In summary, our data provide evidence that the HO-1/ CO/BVD pathway exerts anti-inflammatory and anti-nociceptive effects on the zymosan-induced temporomandibular inflammatory hypernociception in rats. These effects may be dependent on metabolites derived from the HO-1 activity, since the administration of $\mathrm{CO}$ and BVD also reduced inflammatory parameters. In addition, the inhibition of the HO-1 pathway abolished its anti-inflammatory and antinociceptive effects, increasing inflammatory parameters. Considering the well-demonstrated anti-nociceptive and anti-inflammatory effects of HO-1/CO/BVD pathway, the 

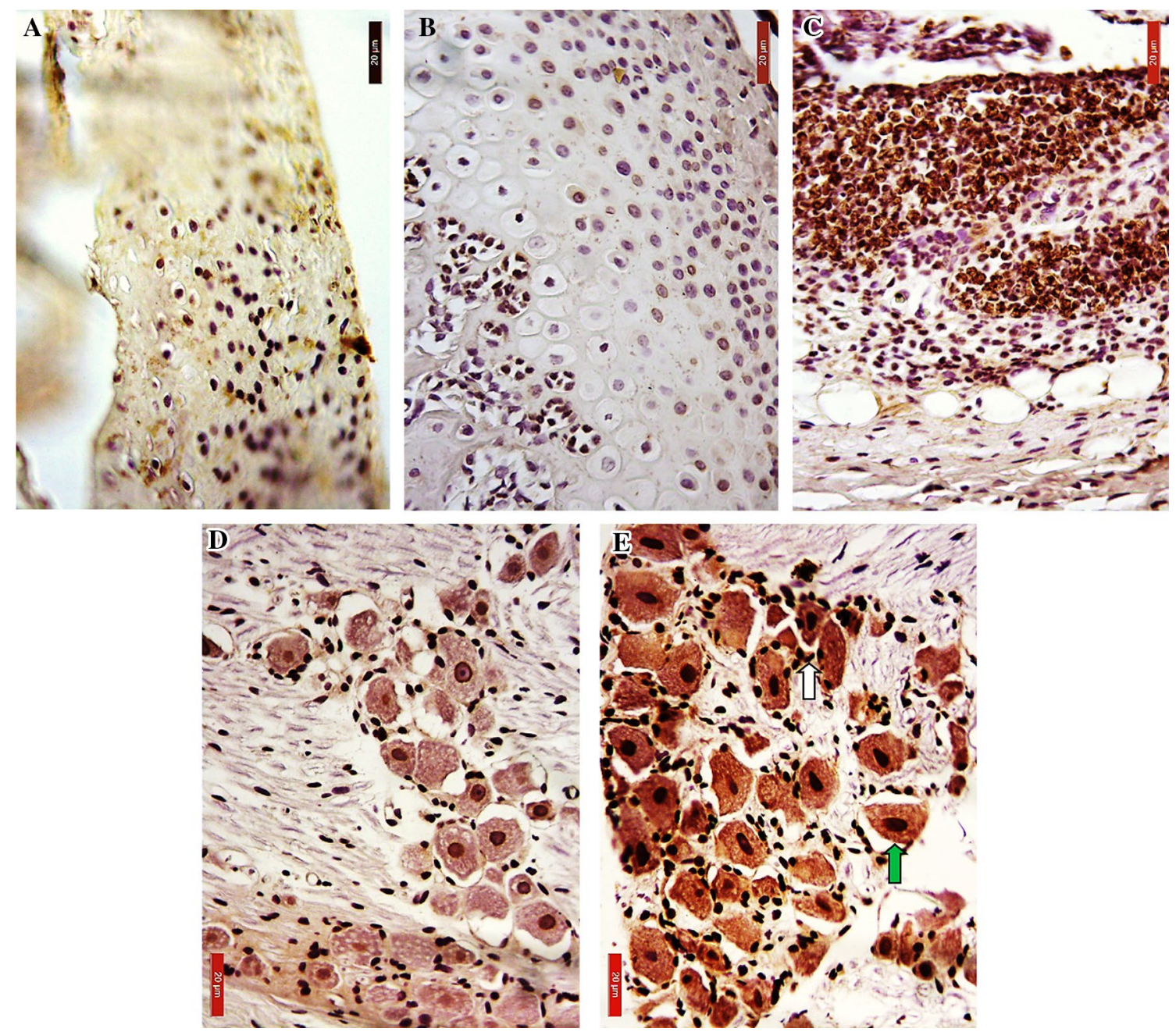

Fig. 8 Immunostaining for IL-1 $\beta$ in the temporomandibular joint and trigeminal ganglion of arthritic animals after zymosan injection. Animals were sacrificed $6 \mathrm{~h}$ after the zymosan injection and the temporomandibular joint was removed for immunohistochemical analysis. a Sham group, b, c TMJ of arthritic animals showing noticeable immunolabeling for IL-1 $\beta$ in chondrocytes (b), neutrophils and

synoviocytes (c) $(400 \times)$. For the immunohistochemical analysis of IL- $1 \beta$ in the trigeminal ganglion, animals were sacrificed $12 \mathrm{~h}$ after the zymosan injection. e sham group, and $\mathbf{f}$ zymosan group showing intense IL-1 $\beta$ immunolabeling in the neuronal body (green arrow) and glial cells (white arrow) (400x)

designing of alternative compounds to classical anti-inflammatory and analgesic agents is very encouraging to define new pharmacological targets of the inflammatory TMJ painful condition.

Acknowledgements This work was supported by Brazilian grants from Fundação Cearense de Apoio ao Desenvolvimento Científico e Tecnológico (FUNCAP), Conselho Nacional de Desenvolvimento Científico e Tecnológico (CNPq), Coordenação de Aperfeiçoamento de Pessoal de Nível Superior (CAPES), and Instituto de Biomedicina do Semi-Árido Brasileiro (INCT-IBISAB).

\section{Compliance with ethical standards}

Conflict of interest The authors declare no conflict of interests regarding the publication of this article.

\section{References}

1. Cairns BE. Pathophysiology of TMD pain-basic mechanisms and their implications for pharmacotherapy. J Oral Rehab. 2010;37:391-410.

2. Greene CS, Klasser GD, Epstein JB. Revision of the American association of dental research's science information statement about temporomandibular disorders. J Can Dent Assoc. 2010;76:a115.

3. Graff-Radford SB, Abbott JJ. Temporomandibular Disorders and Headache. Oral Maxillofac Surg Clin North Am. 2016;28(3):335-49.

4. Gegout P, Gillet P, Chevrier D, Guinchamp C, Terlain B, Netter P. Characterization of zymosan-induced arthritis in the rat: effects on joint inflammation and cartilage metabolism. Life Sci. 1994;55:321-26.

5. Keystone EC, Schorlemmer HU, Pope C, Allison AC. Zymosan induced arthritis. A model of chronic proliferative arthritis 
following activation of the alternative pathway of complement. Arthritis Rheum. 1989;20:1396-401.

6. Rocha FA Jr, Aragão AG, Oliveira RC, Pompeu MM, Vale MR, Ribeiro RA. Periarthritis promotes gait disturbance in zymosaninduced arthritis in rats. Inflam Research. 1999;48:485-90.

7. Chaves HV, Ribeiro RA, Souza AMB, Silva AAR, Gomes AS, Val ML, Bezerra MM, Brito GAC. Experimental model of zymosaninduced arthritis in the rat temporomandibular joint: role of nitric oxide and neutrophils. J Biomed Biotech. 2011. https://doi. org/10.1155/2011/707985.

8. Arinci A, Ademoglu E, Aslan A, Mutlu-Turkoglu U, Karabulut AB, Karan A. Molecular correlates of temporomandibular joint disease. Oral Surg Oral Med Oral Pathol Oral Radiol Endod. 2005;99:666-70.

9. Kaneyama K, Segami N, Sun W, Sato J, Fujimura K. Analysis of tumor necrosis factor-alpha, interleukin-6, interleukin-1beta, soluble tumor necrosis factor receptors I and II, interleukin-6 soluble receptor, interleukin-1 soluble receptor type II, interleukin-1 receptor antagonist, and protein in the synovial fluid of patients with temporomandibular joint disorders. Oral Surg Oral Med Oral Pathol Oral Radiol Endod. 2005;99:276-84.

10. Abraham NG, Lin JH, Schwartzman ML, Levere RD, Shibahara S. The physiological significance of heme oxygenase. Int J Biochem. 1988;20:543-58.

11. Baranano DE, Snyder SH. Neural roles for heme oxygenase: contrasts to nitric oxide synthase. Proc Natl Acad Sci USA. 2001;98:10996-1002.

12. Bonelli M, Savitskaya A, Steiner CW, Rath E, Bilban M, Wagner O, Bach FH, Smolen JS, Scheinecker C. Heme oxygenase-1 end-products carbon monoxide and biliverdin ameliorate murine collagen-induced arthritis. Clin Exp Rheumatol. 2012;30:73-8.

13. Ibáñez L, Alcaraz MJ, Maicas N, Guede D, Caeiro JR, Koenders MI, van den Berg WB, Ferrándiz ML. Up-regulation of the inflammatory response by ovariectomy in collagen-induced arthritis. Effects of Tin Protoporphyrin IX. Inflammation. 2011;34:585-96.

14. Maines MD. Carbon monoxide: an emerging regulatory of cGMP in the brain. Mol Cell Neurosci. 1993;4:389-97.

15. Morita T, Perrella MA, Lee ME, Kourembanas S. Smooth muscle cell-derived carbon monoxide is a regulator of vascular cGMP. Proc Natl Acad Sci USA. 1995;92:1475-79.

16. Otterbein LE, Bach FH, Alam J, Soares M, Tao Lu H, Wysk M, Davis RJ, Flavell RA, Choi AM. Carbon monoxide has antiinflammatory effects involving the mitogen-activated protein kinase pathway. Nat Med. 2000;6:422-8.

17. Petrache I, Otterbein LE, Alam J, Wiegand GW, Choi AM. Heme oxygenase-1 inhibits TNF-alpha-induced apoptosis in cultured fibroblasts. Am J Physiol. 2000;278:312-9.

18. Alcaraz MJ, Fernández P, Guillén MI. Anti-inflammatory actions of the heme oxygenase-1 pathway. Curr Pharm Des. 2003;9:2541-51.

19. McCoubrey WK, Huang TJ, Maines MD. Isolation and characterization of a cDNA from the rat brain that encodes hemoprotein heme oxygenase-3. Eur J Biochem. 1997;247:725-32.

20. Vicente AM, Guillen MI, Habib A, Alcaraz MJ. Beneficial effects of heme oxygenase-1 up-regulation in the development of experimental inflammation induced by zymosan. J Pharmacol Exp Ther. 2003;307:1030-7.

21. Pae HO, Choi BM, Oh GS, Lee MS, Ryu DG, Rhew HY, Kim YM, Chung HT. Roles of heme oxygenase-1 in the antiproliferative and antiapoptotic effects of nitric oxide on Jurkat T cells. Mol Pharmacol. 2004;66:122-8.

22. Bradley PP, Christense RD, Rothstein G. Cellular and extracellular myeloperoxidase in pyogenic inflammation. Blood. 1982;60:618-22.

23. Chi PL, Chen YW, Hsiao LD, Chen YL, Yang CM. Heme oxygenase 1 attenuates interleukin- $1 \beta$-induced cytosolic phospholipase A2 expression via a decrease in NADPH oxidase/reactive oxygen species/activator protein 1 activation in rheumatoid arthritis synovial fibroblasts. Arthritis Rheum. 2012;64(7):2114-25.

24. Clérigues V, Guillén MI, Castejón MA, Gomar F, Alcaraz MJ. Haem oxygenase- 1 counteracts the effects of interleukin- $1 \beta$ on inflammatory and senescence markers in cartilage-subchondral bone explants from osteoarthritic patients. Clin Sci. 2012;122:239-50.

25. Clérigues V, Guillén MI, Castejón MA, Gomar F, Mirabet V, Alcaraz MJ. Heme oxygenase-1 mediates protective effects on inflammatory, catabolic and senescence responses induced by interleukin- $1 \beta$ in osteoarthritic osteoblasts. Biochem Pharmacol. 2012;83:395-405.

26. Grangeiro NMG, Aguiar JA, Chaves HV, Silva AAR, Lima V, Benevides NMB, Graça JR, Bezerra MM. Heme oxygenase/carbon monoxide-biliverdin pathway may be involved in the antinociceptive activity of etoricoxib, a selective COX-2 inhibitor. Pharmacol Rep. 2011;63:112-19.

27. Megías J, Guillén MI, Clérigues V, Rojo AI, Cuadrado A, Castejón MA. Heme oxygenase-1 induction modulates microsomal prostaglandin E synthase-1 expression and prostaglandin E(2) production in osteoarthritic chondrocytes. Biochem Pharmacol. 2009;77:1806-13.

28. Park SY, Lee SW, Shin HK, Chung WT, Lee WS, Rhim BY, Hong $\mathrm{KW}$, Kim CD. Cilostazol enhances apoptosis of synovial cells from rheumatoid arthritis patients with inhibition of cytokine formation via nrf2-linked heme oxygenase 1 induction. Arthritis Rheum. 2010;62:732-41.

29. Hayashi S, Takamiya R, Yamaguchi T, Matsumoto K, Tojo SJ, Tamatani T, Kitajima M, Makino N, Ishimura Y, Suematsu M. Induction of heme oxygenase-1 suppresses venular leukocyte adhesion elicited by oxidative stress: role of bilirrubin generated by the enzyme. Circ Res. 1999;85:663-71.

30. Vachharajani TJ, Work J, Issekutz AC, Granger DN. Heme oxygenase modulates selectin expression in different regional vascular beds. Am J Physiol. 2000;278:1613-7.

31. Benallaoua M, Francois M, Batteux F, Thelier N, Shyy JY, Fitting C. Pharmacologic induction of heme oxygenase 1 reduces acute inflammatory arthritis in mice. Arthritis Rheum. 2007;56:2585-94.

32. Devesa I, Ferrandiz ML, Guillen I, Cerda JM, Alcaraz MJ ${ }^{\mathrm{A}}$. Potential role of heme oxygenase-1 in the progression of rat adjuvant arthritis. Lab Invest. 2005;85:34-44.

33. Devesa I, Ferrándiz ML, Terencio MC, Joosten LAB, Van den Berg WB, Alcaraz $\mathrm{MJ}^{\mathrm{B}}$. Influence of heme oxygenase 1 modulation on the progression of murine collagen-induced arthritis. Arthritis Rheum. 2005;52:3230-38.

34. Bussolati B, Ahmed A, Pemberton H, Landis RC, di Carlo F, Haskard DO, Manson JC. Bifunctional role for VEGF-induced heme oxygenase- 1 in vivo: induction of angiogenesis and inhibition of leukocytic infiltration. Blood. 2004;103:761-66.

35. Kobayashi H, Takeno M, Saito T, Takeda Y, Kirino Y, Noyori $\mathrm{K}$, Hayashi T, Ueda A, Ishigatsubo Y. Regulatory role of heme oxygenase 1 in inflammation of rheumatoid arthritis. Arthritis Rheum. 2006;54:1132-42.

36. Steiner AA, Branco LGS, Cunha GQ, Ferreira SH. Role of the haeme oxygenase/carbon monoxide pathway in mechanical nociceptor hypersensitivity. Brit J Pharmacol. 2001;132:1673-82.

37. Maines MD. The heme oxygenase system: a regulator of second messenger gases. Ann Rev Pharmacol Toxicol. 1997;37:517-54.

38. Guillén MI, Megías J, Gomar F, Alcaraz MJ. Haem oxygenase-1 regulates catabolic and anabolic processes in osteoarthritic chondrocytes. J Pathol. 2008;214:515-22.

39. Nascimento CGO, Branco LGS. Role of the peripheral heme oxygenase-carbon monoxide pathway on the nociceptive response of 
rats to the formalin test: evidence for a cGMP signaling pathway. Eur J Pharmacol. 2007;556:55-61.

40. Nascimento CGO, Branco LGS. Role of the spinal cord heme oxygenase-carbon monoxide-cGMP pathway in the nociceptive response of rats. Eur J Pharmacol. 2008;581:71-6.

41. Carvalho PG, Branco LGS, Leite- Panissi CRA. Involvement of the heme oxygenase-carbon monoxide-cGMP pathway in the nociception induced by acute painful stimulus in rats. Brain Res. 2011;1385:107-13.

42. Cunha FQ, Teixeira MM, Ferreira SH. Pharmacological modulation of secondary mediator systems-cyclic AMP and cyclic GMP on inflammatory hyperalgesia. Br J Pharmacol. 1999;127:671-78.

43. Bezerra MM, Lima V, Girão VCC, Teixeira RC, Graça JRV. Antinociceptive activity of sildenafil and adrenergic agents in the writhing test in mice. Pharmacol Rep. 2008;60:339-44.

44. Sachs D, Cunha FQ, Ferreira SH. Peripheral analgesic blockade of hypernociception: activation of arginine/NO/cGMP/protein kinase G/ATP-sensitive K + channel pathway. Proc Natl Acad Sci USA. 2004;101:3680-5.

45. Fernandez P, Guillen MI, Gomar F, Alcaraz MJ. Expression of heme oxygenase- 1 and regulation by cytokines in human osteoarthritic chondrocytes. Biochem Pharmacol. 2003;66:2049-52.

46. Kitamura A, Nishida K, Komiyama T, Doi H, Kadota Y, Yoshida A, Ozaki T. Increased level of heme oxygenase-1 in rheumatoid arthritis synovial fluid. Mod Rheumatol. 2011;21:150-57.

47. Valvason C, Musacchio E, Pozzuoli A, Ramonda R, Aldegheri $\mathrm{R}$, Punzi L. Influence of glucosamine sulphate on oxidative stress in human osteoarthritic chondrocytes: effects on HO-1, p22Phox and iNOS expression. Rheumatol. 2008;47:31-5.

48. Cunha TM, Verri WA Jr, Silva JS, Poole S, Cunha FQ, Ferreira SH. A cascade of cytokines mediates mechanical inflammatory hypernociception in mice. Proc Natl Acad Sci USA. 2005;102(5):1755-60.

49. Verri WA Jr, Cunha TM, Parada CA, Poole S, Cunha FQ, Ferreira SH. Hypernociceptive role of cytokines and chemokines: targets for analgesic drug development? Pharmacol Ther. 2006;112(1):116-38.

50. Arend WP, Dayer JM. Inhibition of the production and effects of interleukin-1 and tumor necrosis factor alpha in rheumatoid arthritis. Arthritis Rheum. 1995. https://doi.org/10.1002/ art.1780380202.

51. Brennan FM, McInnes IB. Evidence that cytokines play a role in rheumatoid arthritis. J Clin Invest. 2008;118:3537-45.

52. Durham ZL, Hawkins JL, Durham PL. Tumor necrosis factoralpha stimulates cytokine expression and transient sensitization of trigeminal nociceptive neurons. Arc Oral Biol. 2017;75:100-6.

53. Fernández P, Guillén MI, Gomar F, Alcaraz MJ. Expression of heme oxygenase- 1 and regulation by cytokines in human osteoarthritic chondrocytes. Biochem Pharmacol. 2003;15:66:2049-52.

54. Lee TS, Chau LY. Heme oxygenase-1 mediates the anti-inflammatory effect of interleukin-10 in mice. Nat Med. 2002;8:240-6.

55. Paine A, Eiz-Vesper B, Blasczyk R, Immenschuh S. Signaling to heme oxygenase-1 and its anti-inflammatory therapeutic potential. Biochem Pharmacol. 2010;80:1895-903. 